\title{
Yearly Cost Saving by Using Enthalpy Heat Exchanger During Cooling and Heating
}

\author{
Kamil Križo ${ }^{1}$, Andrej Kapjor ${ }^{1}$, and Martin Vantúch $^{1}$ \\ ${ }^{1}$ Department of Power Engineering, Faculty of Mechanical Engineering, University of Zilina, \\ Univerzitna 1, 01026 Zilina, Slovak Republic
}

\begin{abstract}
Fresh air has to be constantly supplied to the building by air handling unit, where supplied air is mixed with inside air and optimal temperature, oxygen level is adjusted and level of dust and smoke is reduced. Supply air demand of the building is determined according to number of persons in the room, room area and regulations. Necessity of ventilation rely in supplying room with oxygen, cleaning the air, adjusting temperature and moisture and reduction of odours, gases, dust, bacteria and viruses. Achieving optimal properties of supply air creates huge portion of building energy consumption. To save energy during ventilation, standard air to air sensible heat exchangers are used. They purpose is to recover sensible heat from exhaust air and at the same time avoid contamination of supply air. Drawback of these types of exchangers is limit of recovering moisture, therefore huge portion of energy in form of latent heat is lost. On top of classical plate air to air heat exchanger, enthalpy heat exchanger allows to exchange latent as well as sensible heat [1].
\end{abstract}

\section{Introduction}

Heat recovery efficiency can be calculated according to three following transfer rates $[2]$.

- Sensible heat recovery efficiency (temperature).

- Latent heat recovery efficiency (humidity).

- Enthalpy recovery efficiency (total heat).

Heat recovery can be calculated if at least two of above mentioned efficiencies are known. If volume flow of supply air is the same as volume of exhaust air heat recovery efficiency is the same. If volume of supply air and exhaust air is not the same, overall

\footnotetext{
${ }^{1}$ Corresponding author: kamil.krizo@fstroj.uniza.sk
} 
efficiency is low, if volume flow of exhaust air is low. Reversely high efficiency is achieved if volume flow of the exhaust air is high.

Sensible heat recovery efficiency under same volume flow of supply and exhaust air $(\%)$

$$
\eta_{t}=\frac{\left(T_{o a}-T_{s a}\right)}{\left(T_{o a}-T_{e a}\right)} 100 \%
$$

Enthalpy recovery efficiency under even volume flow (\%)

$$
\eta_{h}=\frac{h_{o a}-h_{s a}}{h_{o a}-h_{e a}} 100 \%
$$

where: $o a$ - outdoor air, $s a$ - supply air, $r a$ - return air, $e a$ - exhaust air.

If heat recovery efficiency and parameters of outdoor and return air are known, parameters of supply air and exhaust air can be determined as:

Temperature $\left[{ }^{\circ} \mathrm{C}\right]$

$$
\begin{aligned}
& T s a=T_{o a}-\left(T_{o a}-T_{r a}\right) \eta_{T} \\
& T e a=T_{r a}+\left(T_{o a}-T_{r a}\right) \eta_{T}
\end{aligned}
$$

Enthalpy $[\mathrm{kJ} / \mathrm{kg}]$

$$
\begin{aligned}
& h_{s a}=h_{o a}-\left(h_{o a}-h_{r a}\right) \eta_{T} \\
& h_{o v}=h_{r a}-\left(h_{o a}-h_{r a}\right) \eta_{T}
\end{aligned}
$$

Enthalpy of moist air consist of enthalpy of water vapor and enthalpy of dry air

$$
h_{m a}=h_{\text {air }}+x \cdot h_{\text {vapor }}
$$

Where:

$$
\begin{gathered}
h_{\text {vapor }}=2500+1.8 T \\
h_{\text {air }}=c_{p} T
\end{gathered}
$$

$x$ - weight ratio of moisture in the dry air $[\mathrm{g} / \mathrm{kg}], c_{p}$ - specific heat of dry air $[\mathrm{J} / \mathrm{kg} . \mathrm{K}]$.

\subsection{Calculation for enthalpy heat exchanger}

Temperature of supply air - heating in winter

$$
T_{s a}=\left(T_{r a}-T_{o a}\right) \eta_{t}+T_{o a}
$$

Temperature of supply air - cooling in summer

$$
T_{s a}=T_{o a}-\left(T_{o a}-T_{r a}\right) \eta_{t}
$$


Enthalpy of supply air - heating in the winter

$$
h_{s a}=\left(h_{r a}-h_{o a}\right) \eta_{h}+h_{o a}
$$

Enthalpy of supply air - cooling in the summer

$$
h_{s a}=h_{o a}-\left(h_{r a}-h_{o a}\right) \eta_{h}
$$

Heat recovered, heating in the winter [kW]

$$
q_{r}=\left(h_{s a}-h_{o a}\right) \rho \dot{V}
$$

Heat recovered cooling in the summer

$$
q_{r}=\left(h_{r a}-h_{s a}\right) \rho \dot{V}
$$

Outdoor air load, heating in the winter [kW]

$$
q_{l}=\left(h_{s a}-h_{r a}\right) \rho \dot{V}
$$

Outdoor air load, cooling in the summer [kW]

$$
q_{l}=\left(h_{r a}-h_{s a}\right) \rho \dot{V}
$$

\subsection{Calculation for sensible heat exchanger}

Temperature of supply air, heating in the winter

$$
T_{s a}=\left(T_{r a}-T_{o a}\right) \eta_{t}+T_{o a}
$$

Temperature of supply air cooling in the summer

$$
T_{s a}=T_{o a}-\left(T_{o a}-T_{r a}\right) \eta_{t}
$$

Enthalpy of supply air $h_{s a}$ can be read from psychometric table or by equation:

$$
h_{s a}=c_{p s a} T_{s a}+x_{s a}\left(2500+1.84 T_{s a}\right)
$$

Where weight ratio of water vapor in the dry air on supply side is replaced by weight ratio of outer air. In sensible heat exchanger moisture recovery is not present.

Heat recovered, heating in the winter

$$
q_{r}=\left(h_{o a}-h_{s a}\right) \rho \dot{V}
$$

Heat recovered, cooling in the summer

$$
q_{s}=\left(h_{r a}-h_{o a}\right) \rho \dot{V}
$$

Outer air load, heating in the winter 


$$
q_{z}=\left(h_{s a}-h_{r a}\right) \rho \dot{V}
$$

Outdoor air load, cooling in the summer

$$
q_{l}=\left(h_{r a}-h_{s a}\right) \rho \dot{V}
$$

Enthalpy recovery efficiency

$$
\eta_{h}=\frac{q_{s}}{\left(q_{s}+q_{z}\right)} 100
$$

\subsection{Conventional ventilator}

During ventilation with conventional air ventilator enthalpy of supply air is the same as enthalpy of outer air and enthalpy of exhaust air same as enthalpy of return air. Heat recovered is $0 \mathrm{kcal}$ and outdoor air load is calculated as:

$$
q_{s}=\left(h_{r a}-h_{o a}\right) \rho \dot{V}
$$

\subsection{Ventilation operation time}

Operation time in hours

$$
\text { VOT }=\text { hours/day } * \text { days/months } * \text { months/ year }
$$

Energy for heating $[€ / \mathrm{kWh}]$

$$
U_{\text {heat }}=\text { electricity cost } / \text { COP }
$$

Energy cost for cooling [€/kWh]

$$
U_{\text {cool }}=\text { electricity cost } / \mathrm{COP}
$$

- $\mathrm{COP}$ - coefficient of performance

\subsection{Yearly saved money [€]}

$$
\text { Early saved money }=q_{s} . U_{\text {heat. }} \text { OT }
$$

Heat recovered [\%]

$$
H R=\left(\frac{100}{q_{z}}\right) q_{s}
$$

\subsection{Solution}

Graphs (Figure 1, 2 and 3) below shows early savings by using sensible heat exchanger and enthalpy heat exchanger.

Volume flow: $8000 \mathrm{~m}^{3} / \mathrm{h}$ 
Winter conditions

$T_{s a}=15.8{ }^{\circ} \mathrm{C}, x_{s a}=5.1 \mathrm{~g} / \mathrm{kg}$, relative humidity $46 \%$

$T_{o a}=0{ }^{\circ} \mathrm{C}, x_{o a}=1.9 \mathrm{~g} / \mathrm{kg}$, relative humidity $50 \%$

$T_{r a}=20^{\circ} \mathrm{C}, x_{r a}=7.2 \mathrm{~g} / \mathrm{kg}$, relative humidity $50 \%$

Summer conditions

$T_{s a}=27.5^{\circ} \mathrm{C}, x_{s a}=14.0 \mathrm{~g} / \mathrm{kg}$, relative humidity $61 \%$

$T_{o a}=33{ }^{\circ} \mathrm{C}, x_{o a}=20.1 \mathrm{~g} / \mathrm{kg}$, relative humidity $63 \%$

$T_{r a}=26{ }^{\circ} \mathrm{C}, x_{r a}=10.5 \mathrm{~g} / \mathrm{kg}$, relative humidity $50 \%$

Next Tables 1, 2 and 3 shows physical parameter of heat exchanger in year seasons.

Table 1. Operation conditions and energy cost.

\begin{tabular}{|c|c|c|}
\hline & Summer - cooling & Winter - heating \\
\hline Hours/day & 10.5 & 10.5 \\
\hline Days/month & 26 & 26 \\
\hline Months/year & 4 & 5 \\
\hline Operation time h/yr & 1606.5 & 2226 \\
\hline Electricity cost $[€ / \mathrm{kW}]$ & 0.0712 & 0.0712 \\
\hline $\begin{array}{c}\text { Capacity per } 1 \mathrm{~kW} \text { of electricity } \\
{[\mathrm{kW} / \mathrm{kW}]}\end{array}$ & 2.6 & 3.1 \\
\hline Energy unit cost $[€ / \mathrm{kW}]$ & 0.03 & 0.02 \\
\hline
\end{tabular}

Table 2. Performance enthalpy heat exchanger.

\begin{tabular}{|c|c|c|}
\hline Enthalpy heat exchanger & Summer -cooling & Winter - heating \\
\hline Yearly savings [€] & 2501 & 3287 \\
\hline Outdoor air load [kW] & 84.77 & 89.91 \\
\hline Heat recovered [kW] & 56.85 & 64.28 \\
\hline Heat recovered [\%] & 67.1 & 71.5 \\
\hline$\eta_{t}[\%]$ & 78.57 & 79.00 \\
\hline$\eta_{h}[\%]$ & 67.06 & 71.50 \\
\hline
\end{tabular}

Table 3. Performance sensible heat exchanger.

\begin{tabular}{|c|c|c|}
\hline Sensible heat exchanger & Summer -cooling & Winter - heating \\
\hline Yearly savings [€] & 1228 & 2183 \\
\hline Outdoor air load [kW] & 84.77 & 89.91 \\
\hline Heat recovered [kW] & 27.92 & 42.70 \\
\hline Heat recovered [\%] & 32.9 & 47.5 \\
\hline$\eta_{t}[\%]$ & 78.57 & 79.00 \\
\hline$\eta_{h}[\%]$ & 18.11 & 47.50 \\
\hline
\end{tabular}


Yearly saved money $[€]$

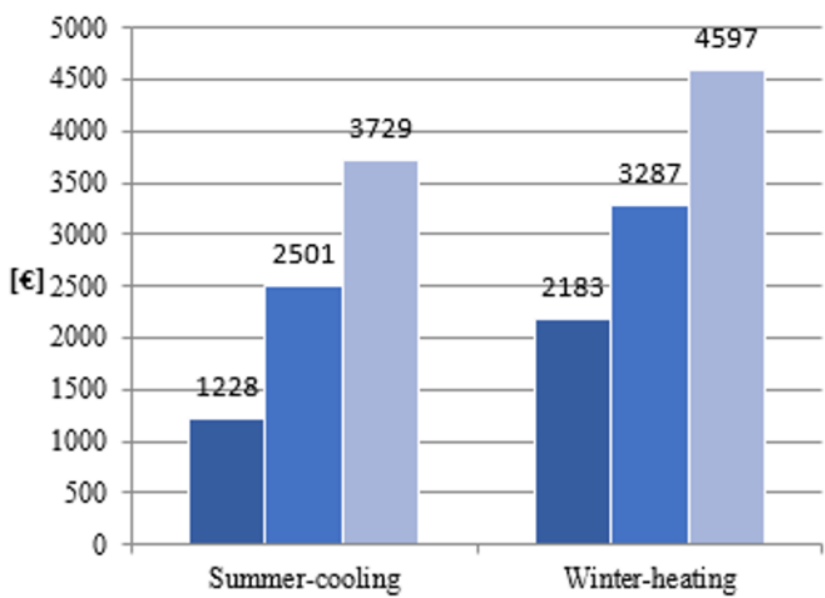

- Early saved money sensible heat exchanger

- Early saved money enthalpy heat exchanger

Fig. 1. Yearly saved money for cooling and heating under given conditions.

\section{Heat recovered [\%]}

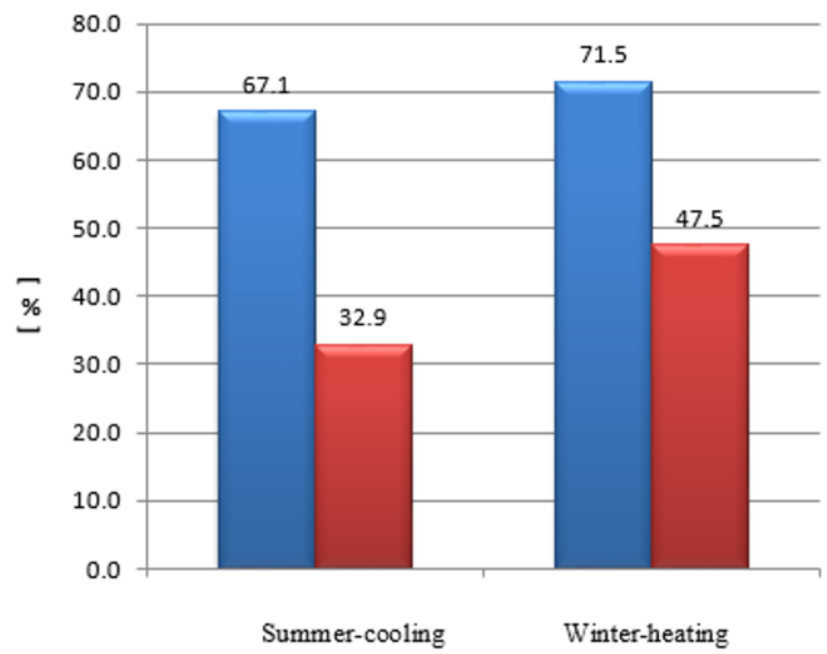

neat recovered with enthalpy heat exchanger

- Heat recovered with sensible heat exchanger

Fig. 2. Heat recovered [\%]. 


\section{Heat recovery efficiency $\eta[\%]$}

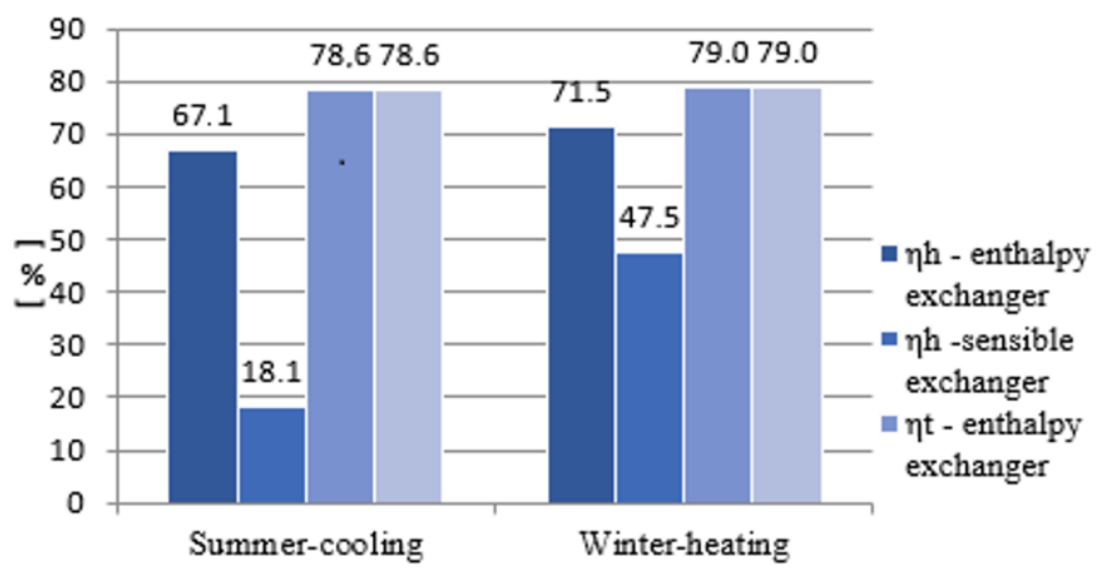

Fig. 3. Heat recovery efficiency of enthalpy and sensible heat exchanger.

\section{Conclusion}

Results show significant contribution of enthalpy heat exchanger in reducing the latent load and significant potential in energy saving in compare to sensible heat exchanger. Sensible heat efficiency for both types of exchangers and enthalpy have the same value assuming same geometry, air conditions and very thin plates accounting for minimal heat transfer resistance. On the other hand recovered moisture accounts for significant difference in enthalpy recovery efficiency where this value can reach $67 \%$ in the summer and $71.5 \%$ in the winter for enthalpy heat exchanger and $18.1 \%$ in the summer and $47.5 \%$ in the winter for sensible heat exchanger. Under given air conditions and volume flow it is possible to save $49 \%$ more costs during cooling in summer and $35 \%$ more costs during heating in winter just by using enthalpy heat exchanger.

This article was supported by project KEGA 038ŽU-4/2019 "Flow visualization in environmental engineering".

\section{References}

1. M. S. Nasif, Analysis and Modelling of Membrane Heat Exchanger in HVAC Energy Recovery Systems. 63 (2008)

2. LGH-RX4 Technical manual. 22-24 (2005)

3. S. Gavlas, P. Ďurčanský, R. Lenhard and J. Jandačka, EPJ Web of Conferences 92, (2015)

4. J. Siazik, M. Malcho, S. Gavlas, MATEC Web of Conferences 168, (2018)

5. L. Dabek, A. Kapjor, L. J. Ormam, MATEC Web of Conferences 168, 07001 (2018)

6. S. Tafelmeier, G. A. Longo, A. Gasparella, Internat. high perform. build. conf. 196, (2016) 